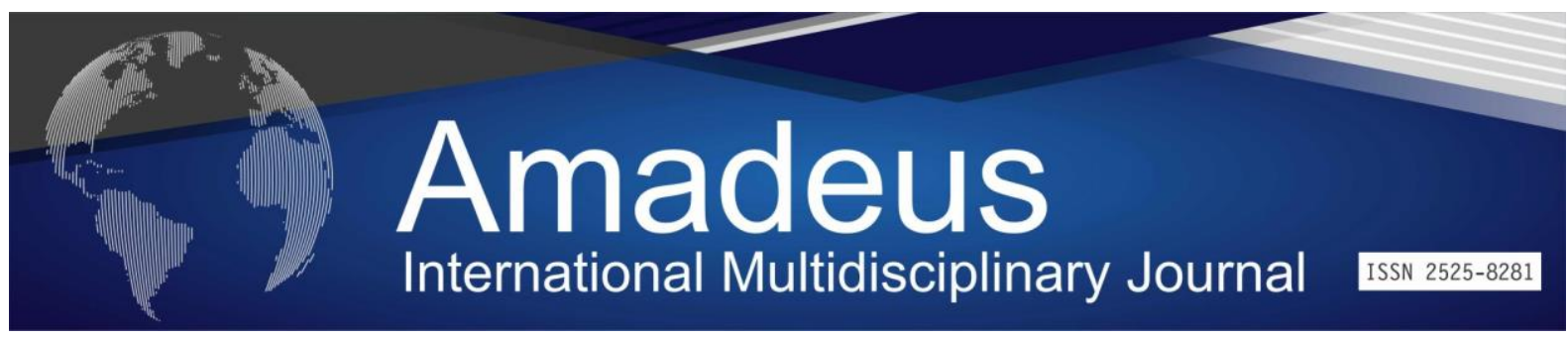

DOI: 10.14295/aimj.v4i7.96

\title{
Anencephaly as Congenital Malformation and Critical Issues Involved
}

Eduarda Monteiro Jovino ${ }^{1}$; Marianna Leite Barroso ${ }^{2}$; Ana Karoline de Oliveira Florêncio ${ }^{3}$ Jucier Gonçalves Júnior

\begin{abstract}
Congenital malformations constitute alterations in the structure, physiological functioning or metabolism of cells, tissues and / or organs, causing morphological, biochemical or behavioral defects produced during pregnancy. Approximately $20 \%$ of pregnancies with malformed fetuses end in spontaneous abortion and the remaining $80 \%$ will be born dead or alive, resulting in $3 \%$ to $5 \%$ of newborns with congenital anomalies. This study discusses aspects related to anencephaly and other critical issues surrounding this context. It was concluded that the right to life is fundamental, constituting a prerequisite for the existence and exercise of all other rights. Even so, there still seems to be bias in the legislation that enables parents of babies with this malformation to have legal recourse to abortion.
\end{abstract}

Keywords: Malformations, Anencephaly, Right to life.

1 Graduated in Medicine from the Federal University of Cariri - UFCA. Family Health Strategy Physician.dudajovino@gmail.com;

${ }^{2}$ Undergraduate Nursing, Faculty of Nursing SãoVicente de Paula. Master in Public Health from the Federal University of Pernambuco. Post Graduation in Public Health, Obstetric Nursing and Family Health. Contact: mariannaleite@ @hotmail.com;

${ }^{3}$ MD, University of Fortaleza - UNIFOR. karolflorencio@gmail.com;

${ }^{4}$ Resident in Clinical Medicine at Santa Casa de Misericórdia of Fortaleza. Degree in MEDICINE from the Federal University of Cariri - UFCA. Certified by the American Heart Association (AHA) / IPATRE at Advanced Cardiovascular Life Support. Contact: juciergjunior@ hotmail.com. 


\section{Anencefalia enquanto Malformação Congênita e Questões Críticas Envolvidas}

\begin{abstract}
Resumo: As malformações congênitas constituem alterações na estrutura, no funcionamento fisiológico ou no metabolismo de células, tecidos e/ou órgãos, ocasionando defeitos morfológicos, bioquímicos ou de conduta, produzidos durante a gestação. Aproximadamente $20 \%$ das gestações com fetos malformados terminam em abortamento espontâneo e os $80 \%$ restantes nascerão mortos ou vivos, resultando estes últimos sem 3\% a 5\% de recém-nascidos com anomalias congênitas. Este estudo discute aspectos relacionados a anencefalia e outras questões críticas que envolvem este contexto. Concluiu-se que o direito à vida é fundamental, constituindo-se em pré-requisito à existência e exercício de todos os demais direitos. Mesmo assim, parece ainda haver vieses na legislação que possibilitam que os pais de bebês com essa malformação, possam recorrer judicialmente ao direito de praticar o aborto.
\end{abstract}

Palavras-chave: Malformações, Anencefalia, Direito à vida.

\section{Introdução}

Anencefalia consiste em malformação congênita caracterizada pela ausência total ou parcial do encéfalo, proveniente de defeito de fechamento do tubo neural durante a formação embrionária, entre os dias 23 e 28 da gestação ${ }^{1}$. Isso leva a progressiva destruição da massa encefálica em razão de sua exposição ao líquido amniótico ${ }^{2,3}$. A anencefalia somente é perceptível por volta do $25^{\circ}$ dia após a fecundação ${ }^{4,5}$.

Os defeitos do tubo neural apresentam espectro variável, sendo os mais comuns a anencefalia e a espinha bífida ${ }^{6}$. Esse grupo, além de maior risco de mortalidade, representa maior morbidade ${ }^{7}$.

Na América do Sul, estima-se que a prevalência de defeitos do tubo neural seja de 1,5 por mil nascimentos, integrada por 0,4 de anencefalia, 0,8 de espinha bífida e 0,3 de encefalocele ${ }^{8}$.

Essa malformação ocorre com maior frequência em fetos femininos, pois, parece estar ligado ao cromossomo $\mathrm{X}^{1}$. Apesar de avanços da genética médica e molecular, sua etiologia ainda permanece parcialmente obscura. Podem ter origem genética (distúrbio em um único gene, aberrações cromossômicas), ambiental (exposição a teratógenos) ou multifatorial ${ }^{9}$. 
As principais características são a falta de desenvolvimento da calota craniana, couro cabeludo e, principalmente, o comprometimento da parte anterior do encéfalo que origina os hemisférios cerebrais ${ }^{10,11}$. O cerebelo, o tronco cerebral e os nervos ópticos podem estar malformados, o hipotálamo está tipicamente ausente e, em consequência, as adrenais são sempre hipoplásicas ${ }^{12}$.

A criança é comumente cega, surda, inconsciente, e incapaz de sentir dor (National Institute Of Neurological Disordes And Stroke), repercutindo diretamente na consciência, no poder de cognição, comunicação, sentimentos do indivíduo ${ }^{13}$. Além disso, o córtex é essencial para a maioria dos processos envolvidos com o pensamento e sem ele a função dos outros centros é imprecisa, pois são seus comandos que tornam as operações desses centros precisas e determinativas ${ }^{12}$.

As porções médias e posterior do encéfalo podem ter grau variado de desenvolvimento, chegando a permitir que essas crianças respirem espontaneamente, chorem, deglutem, façam expressões faciais, movimentem os membros e respondam a estímulos nocivos ${ }^{10}{ }^{11}$, além das funções vasomotoras e outras dependentes da medula espinhal ${ }^{14}$.

Com isso, a anencefalia é considerada um grave defeito embrionário do sistema nervoso central $^{12}$. Dessa forma, considera-se o feto anencéfalo como potencialmente impossibilitado de sobreviver no ambiente extrauterino, ou seja, fora do útero materno ${ }^{13}$. A anomalia pode ser diagnosticada, com muita precisão, a partir de 12 semanas de gestação, através de exame ultrassonográfico, quando já é possível a visualização do segmento cefálico fetal ${ }^{1}$.

$\mathrm{O}$ risco de incidência de anencefalia aumenta $5 \%$ a cada gravidez subsequente. Inclusive, mães diabéticas têm 6 vezes maior probabilidade de gerar filhos com este problema. Há também maior incidência de casos de anencefalia em mães muito jovens ou nas de idade avançada ${ }^{1}$. Em relação à idade materna, existe um maior acometimento em filhos de mulheres com mais de 35 anos e com nível socioeconômico desfavorável ${ }^{15}$.

Devido à gravidade e a alta morbidade e letalidade das malformações congênitas do sistema nervoso central, torna-se importante o diagnóstico pré-natal, o aconselhamento genético e a suplementação dietética com ácido fólico preconcepcional para mulheres que desejam gestar, posto que reduz os riscos de ocorrência e de recorrência de defeitos do tubo neural em torno de $50 \%$ a $70 \%{ }^{6,16}$. O ácido fólico só previne os defeitos de fechamento do tubo neural, sendo que seu efeito protetor só ocorre se a suplementação for iniciada antes da gestação ${ }^{17}$.

Além disso, existem vários outros fatores que podem ocasionar o aparecimento de anencefalia, dentre eles estão: radiações, vírus, administrações de determinadas drogas durante o período gestacional, contato direto com produtos tóxicos, sendo o fator de risco mais importante, a ausência de ácido fólico no metabolismo das mães gestantes ${ }^{15}$. 
Vale ressaltar que a anencefalia não é uma deficiência. Não existem crianças e nem adultos anencéfalos, muito menos tratamentos e nem reversão do quadro do feto detectado como anencéfalo ${ }^{14}$. Portanto, não há cura para a anencefalia. Ela é letal em 100\% dos casos. Não há nenhuma possibilidade de tratamento do feto após o diagnóstico ${ }^{18}$.

Por isso, o monitoramento permanente da ocorrência de deficiências e incapacidades nas crianças, assim como a análise da prevalência e sua tendência, constituem metas a serem alcançadas pelos serviços de saúde, objetivando o planejamento de procedimentos e avaliação das medidas preventivas ${ }^{19}$.

\section{A interrupção da gravidez}

$\mathrm{Na}$ antiguidade havia controvérsias sobre o aborto ${ }^{20}$. Na Grécia antiga, por exemplo, as crianças indesejadas eram simplesmente abandonadas pelos pais após o nascimento. Aristóteles sustentava que o aborto era um método eficaz para limitar nascimentos e evitar o crescimento populacional exacerbado, mantendo estáveis as populações das cidades gregas ${ }^{21}$. Platão defendia o aborto obrigatório por razões eugênicas, para mulheres com mais de 40 anos e para preservar a pureza dos guerreiros. Sócrates também defendia o aborto, desde que esse fosse o desejo da gestante. Assim, a prática abortiva era comum entre os povos antigos ${ }^{20}$. O direito Romano, de início, não estabelecia qualquer punição ao aborto. Somente depois, com o cristianismo é que o império romano, com a força religiosa passou a punir a prática do aborto ${ }^{20}$. Logo, foi com o surgimento do cristianismo que avida passou a ser vista como um valor supremo, com ares de sacralidade e intangibilidade ${ }^{22}$.

Percebe-se que a questão do aborto constitui matéria polêmica que envolve as mais diversas facetas do homem e resultam em discussões de cunho religioso, moralista, ético, demagógico, político, biológico, médico, jurídico, econômico e qualquer outro ponto da natureza humana ${ }^{23}$. Assim, a discussão desta temática no Brasil é delicada ${ }^{24}$, pois envolvem princípios e direitos fundamentais e humanos e muitas vezes empregam direitos de mesma natureza, ora para sustentar argumentos a favor da manutenção da conduta como crime tipificado, ora para defender a descriminalização do aborto ${ }^{23}$.

A atenção humanizada às mulheres em abortamento merece abordagem ética e reflexão sobre os aspectos jurídicos, tendo como princípios norteadores a igualdade, a liberdade e a dignidade da pessoa humana, não se admitindo qualquer discriminação ou restrição ao acesso à assistência à saúde ${ }^{25}$.

Ao referir o aborto, é válido salientar que este se caracteriza pela interrupção da gravidez até a $20^{\mathrm{a}}$ ou $22^{\mathrm{a}}$ semana, e com "produto" da concepção pesando menos que $500 \mathrm{~g}$, sendo este "produto" eliminado no processo de abortamento ${ }^{24}$. 
Por tratar-se de tema bastante polêmico, fez-se necessário uma maior abrangência de significação a esse termo. Para $\mathrm{Nucci}^{26}$, o aborto é a "cessação da gravidez, antes do tempo normal, causando a morte do feto". Segundo Prado ${ }^{27}$, entende-se por aborto (de ab-ortus: privação do nascimento) a interrupção voluntária da gravidez, com a destruição do produto da concepção. É a morte do ovo (até três semanas de gestação), embrião (de três semanas a três meses) ou feto (após três meses), não implicando necessariamente sua expulsão. Para Moisés ${ }^{28}$ o aborto é a morte provocada ou espontânea de um menino ou menina no ventre de sua mãe, produzida durante qualquer momento da etapa que vai desde a fecundação (união do óvulo com o espermatozoide) até antes do nascimento.

O abortamento pode ser classificado em precoce, quando ocorre no primeiro trimestre; e tardio, no segundo trimestre; no primeiro trimestre, cerca de $70 \%$ dos abortamentos ocorrem devido a anormalidades cromossômicas; no segundo trimestre são decorrente de doenças maternas, como anomalias uterinas congênitas, infecções maternas, insuficiência istmo-cervical e estados trombóticos ${ }^{29,30}$.

O abortamento representa um grave problema de saúde pública, com maior incidência em países em desenvolvimento, sendo uma das principais causas de mortalidade materna no mundo, inclusive no Brasil ${ }^{31}$. Ao se tratar de questões como o aborto, é preciso considerar a situação brasileira de desigualdade e exclusão social de uma parcela da população, cujos efeitos atingem especialmente mulheres e jovens ${ }^{24}$.

Enfrentar com seriedade esse fenômeno significa entendê-lo como uma questão de cuidados em saúde e direitos humanos, e não como um ato de infração moral de mulheres levianas ${ }^{32}$.

Estima-se, no Brasil, que mais de um milhão de abortos inseguros sejam realizados por ano ${ }^{33}$. A Organização Mundial da Saúde (OMS) define aborto inseguro como o procedimento utilizado para interromper uma gravidez, realizado por pessoas não habilitadas ou em ambiente não adequado. $\mathrm{O}$ aborto é um ato exclusivo de médicos, sendo vedado a enfermeiras ou parteiras realizá-lo mesmo em regiões longínquas do país ${ }^{34}$. Abortos inseguros ocorrem em países onde as leis são restritivas ao procedimento ou naqueles onde é legal, porém, o acesso das mulheres aos serviços de saúde é dificultado ${ }^{35}$. Quando a mulher recorre ao aborto inseguro, fica exposta ao risco de agravos à sua saúde e até à morte ${ }^{24}$.

Considerando que nascem aproximadamente três milhões de crianças por ano no país, pode-se dizer que uma em cada quatro gravidezes termina em aborto ${ }^{33}$. Em um estudo realizado em 2010, em áreas urbanas do Brasil, 22\% das mulheres aos 40 anos relataram ter realizado pelo menos um aborto provocado, a maioria utilizando medicamento Misoprostol ${ }^{36}$. 
Os abortamentos podem ser classificados em: a) Ameaça de abortamento; b) Abortamento completo; c) Abortamento inevitável/incompleto; d) Abortamento retido; e) Abortamento infectado; e f) Abortamento habitual;

Abaixo, discorremos brevemente sobre cada tipo, qualificando sua natureza bem como tentando encontrar as principais diferenças entre os tipos.

Ameaça de Abortamento: Ameaça de aborto é a presença de sangramento transvaginal antes de 20 semanas de gestação, associado ou não a dores por contrações uterinas ${ }^{37}$. O colo uterino (orifício interno) encontra-se fechado, o volume uterino é compatível com o esperado para a idade gestacional, e não existem sinais de infecção ${ }^{25}$. A vitalidade do concepto é um aspecto indispensável na abordagem de uma ameaça de aborto. Para este fim, a ultrassonografia é uma ferramenta fundamental ${ }^{37}$.

Não existe indicação de internação hospitalar, a mulher deve ser orientada para ficar em repouso, utilizar analgésico se apresentar dor, evitar relações sexuais durante a perda sanguínea, e retornar ao atendimento de pré-natal ${ }^{31}$.

Abortamento completo: Epílogo frequente até oito semanas de gestação. Supõe-se o abortamento completo quando, após a expulsão do ovo, cessam as cólicas e o sangramento reduz-se a perdas discretas ${ }^{38}$. O colo uterino (orifício interno) pode estar aberto e o tamanho uterino mostra-se menor que o esperado para a idade gestacional. No exame de ultrassom encontra-se cavidade uterina vazia ou com imagens sugestivas de coágulos ${ }^{25}$. Usualmente evolvem satisfatoriamente e não necessitam de esvaziamento cirúrgico ${ }^{38}$.

Quando o aborto é inevitável: O sangramento é maior que na ameaça de abortamento, que diminui com a saída de coágulos ou de restos ovulares, as dores costumam ser de maior intensidade que na ameaça, e o orifício cervical interno encontra-se aberto. $\mathrm{O}$ exame de ultrassom confirma a hipótese diagnóstica, embora não seja imprescindível ${ }^{31}$. Para o abortamento incompleto o tratamento expectante ou médico (misoprostol) é satisfatório em 80$95 \%$ dos casos. É o cirúrgico a aspiração a vácuo e a curetagem ${ }^{38}$.

Abortamento retido: Em geral, o abortamento retido cursa com regressão dos sintomas e sinais da gestação, o colo uterino encontra-se fechado e não há perda sanguínea. O exame de ultrassom revela ausência de sinais de vitalidade ou a presença de saco gestacional sem embrião (ovo anembrionado). Pode ocorrer o abortamento retido sem os sinais de ameaça ${ }^{25}$. O uso de análogos sintéticos da prostaglandina (misoprostol) representa o tratamento médico de eleição para o abortamento ${ }^{25}$.

Abortamento infectado: $\mathrm{O}$ aborto infectado ou séptico decorre da eliminação incompleta do ovo, do embrião ou da placenta, que mantém aberto o canal cervical, favorecendo a ascensão de bactérias da microbiota vaginal e intestinal à cavidade uterina ${ }^{39}$. São casos mais graves e devem ser tratados, independentemente da vitalidade fetal. As manifestações clínicas 
mais frequentes são: elevação da temperatura, sangramento genital com odor fétido acompanhado de dores abdominais ou eliminação de secreção purulenta através do colo uterino ${ }^{31}$.

Aborto habitual: O abortamento habitual ou recorrente é definido com duas ou três interrupções sucessivas da gravidez, ocorrendo em cerca de $1 \%$ das mulheres em idade reprodutiva ${ }^{38}$. É primário quando a mulher jamais conseguiu levar a termo qualquer gestação, e secundário quando houve uma gravidez a termo. Estas mulheres devem ser encaminhadas para tratamento especializado, onde seja possível identificar as causas e realizados tratamentos específicos ${ }^{25}$.

\section{A prática do Aborto no Brasil}

\section{Aborto Consentido}

No aborto praticado com o consentimento da gestante, ela permite que um terceiro pratique os atos necessários para interromper a gestação, desta maneira a gestante responde pelo delito previsto no artigo 124 , caput, $2^{\mathrm{a}}$ parte, e o terceiro na forma do artigo 126 , caput, ambos do Código Penal. Cabe ressaltar que é necessário o consentimento da gestante para que caracterize o delito de aborto consentido ${ }^{27}$.

\section{Aborto Provocado sem Consentimento da Gestante}

É a modalidade de aborto que acontece quando a interrupção da gravidez ocorre contra a vontade da gestante, no caso também vítima do crime ${ }^{14}$.

Se a gestante não consentir com o aborto, o terceiro responde pelo artigo 125 do Código Penal, que possui pena mais grave, todavia se houver o consentimento da gestante o fato não será atípico, e sim caracterizará o aborto consentido da gestante, que possui tipo penal autônomo $0^{5,40}$.

Essa é a modalidade considerada mais grave, tendo em vista a ausência de consentimento por parte da gestante no emprego dos meios ou manobras abortivas por terceiro ${ }^{48}$.

\section{Aborto Provocado com o Consentimento da Gestante}

De acordo com o artigo 126 do código penal o aborto é provocado por um terceiro, mas com o consentimento da gestante. Nesse caso, tanto a gestante como o terceiro, praticam crimes, 
sendo que a gestante responderá pelo crime previsto no artigo 124 do Código Penal (auto aborto) e o terceiro, responderá pelo que prevê o artigo 126 (aborto consentido) ${ }^{14}$.

É importante ressaltar que o consentimento da gestante somente será válido se for maior de 14 anos e capaz 5 .

\section{Aborto Legal}

São espécies de aborto legal, somete aqueles em que a lei permite sua realização, isentando de pena o médico que vier a provocá-lo nas situações descritas nos incisos do art. 128 do Código Penal ${ }^{41}$. O aborto legal está previsto no art. 128 do Código Penal, e dispõem que:

I - se não há outro meio de salvar a vida da gestante;

II - se a gravidez resulta de estupro e o aborto é precedido de consentimento da gestante ou, quando incapaz, de seu representante legal.

\section{Aborto Qualificado}

Trata-se de crime preterdoloso, em que há dolo para a realização do aborto e culpa para o resultado lesão corporal grave ou morte ${ }^{5,14,42}$.

Assim, a morte ou a lesão corporal de natureza grave deve necessariamente possuir um nexo de causalidade com as manobras abortivas, independente do lapso temporal de sua ocorrência, caso contrário não caracteriza o aborto qualificado pelo resultado ${ }^{41}$.

\section{Aborto Eugênico ou Eugenésio}

Consiste na realização do aborto "quando existam riscos fundados de que o embrião ou feto sejam portadores de graves anomalias genéticas de qualquer natureza ou de outros defeitos físicos ou psíquicos decorrentes da gravidez" ${ }^{27}$.

Dentre as anomalias do feto podemos citar como exemplo os fetos anencéfalos, que entre outras anomalias impossibilita uma vida extrauterina ou de pouca duração ${ }^{14}$.

\section{Legislação brasileira que envolve as questões relacionadas ao Aborto}

O Código Penal Brasileiro (artigo 128 do Código Penal Brasileiro de 1940) define o aborto como interrupção da gravidez com a consequente morte do feto ${ }^{43}$.

O aborto no Brasil é crime. Isso significa que as mulheres devem se manter grávidas, não importando se planejaram ou desejaram a gestação. A gestação é um dever imposto pelo estado às mulheres, sob a alegação de ser este um ditame da natureza que, quando violado, acarretaria a interrupção de uma vida ${ }^{44}$. 
É claro que essa questão tem que ser vista com cuidado. Não se pode simplesmente liberar tal possibilidade e deixá-la a mercê de qualquer um que se ache no direito de praticar essa interrupção. Esta medida, que como uma prisão cautelar, deve ser vista como de exceção, só pode ser autorizada em casos realmente comprovados e necessários ${ }^{45}$.

Assim, o Código penal brasileiro classifica o aborto (auto e heteroaborto) como crime contra a vida. Os únicos três casos nos quais pode ser praticado legalmente por médicos são: risco de vida da gestante, gravidez resultante de estupro e, desde abril de 2012, anencefalia ${ }^{46}$. Assim aborto no Brasil só é aceito nos casos previstos no art. 128.

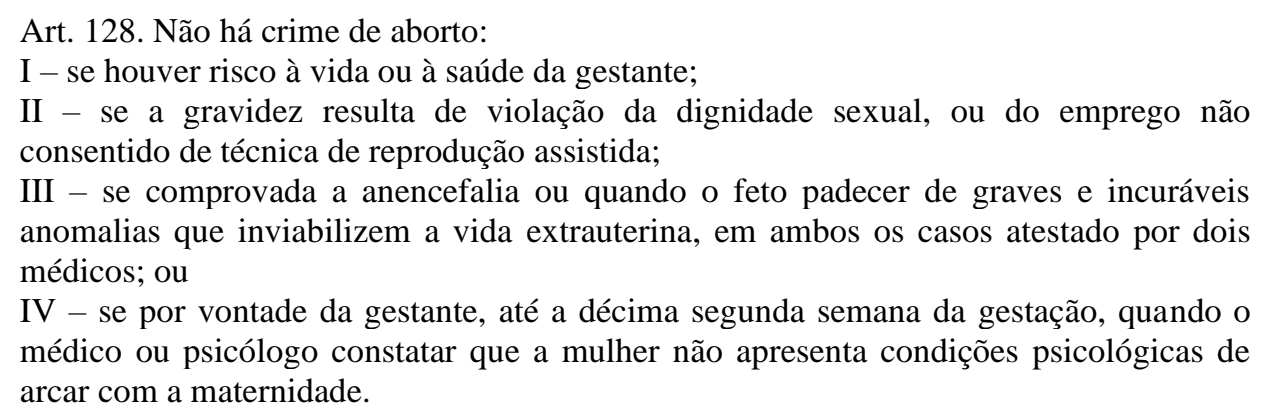

Vale ressaltar que antes da decisão do STF que permitiu a antecipação do parto em caso de anencefalia, o aborto anencefálico já era tratado pelos criminalistas como excludente da ilicitude da conduta, pois não haveria bem jurídico a ser tutelado, na medida em que a criminalização do aborto visa a supressão de condutas que violem o direito fundamental à vida, enquanto esta não estaria presente em caso de anencefalia ${ }^{23,47}$.

Pode-se refletir também em quando se compara os outros casos que são permitidos a realização do aborto, os quais parecem ser muito mais graves do que a interrupção do feto anencéfalo, pois no caso do aborto, o feto retirado é saudável e, em tese, possuiria todas as possibilidades de vida, enquanto que o feto anencéfalo não possui essa chance já que, ou nascerá morto ou morrerá logo após o parto, além de possuir a agravante de colocar em risco a saúde da gestante, logo, se é permitida a interrupção nos casos de aborto que é mais, nada mais justo que se permitirem também nos casos de anencefalia ${ }^{45}$.

\section{Arguição de descumprimento de preceito fundamental no 54}

Arguição de Descumprimento de Preceito Fundamental trata-se de uma espécie de ação que visa evitar ou reparar lesão a preceito fundamental resultante de ato do Poder Público (União, estado, Distrito Federal e município), ou quando for relevante o fundamento da controvérsia constitucional sobre lei ou ato normativo federal, estadual ou municipal anteriores à Constituição Federal ${ }^{48,49}$. 
A Constituição Federal dispõe sobre a arguição de descumprimento de preceito fundamental em seu artigo 102, § $1^{\circ}$ : "A arguição de descumprimento de preceito fundamental, decorrente desta Constituição, será apreciada pelo Supremo Tribunal Federal (STF), na forma da lei."

A referida Lei é a de $\mathrm{n}^{\circ}$ 9.882, sancionada em 3 de dezembro de 1.999. Dispõe sobre o processo e julgamento da arguição de descumprimento de preceito fundamental, nos termos do $\S 1$ o do art. 102 da Constituição Federal ${ }^{48}$. Seguem os dois primeiros artigos da referida lei:

Art. $1^{\circ}$ A arguição prevista no $\S 10$ do art. 102 da Constituição Federal será proposta perante o Supremo Tribunal Federal, e terá por objeto evitar ou reparar lesão a preceito fundamental, resultante de ato do Poder Público. Parágrafo único. Caberá também arguição de descumprimento de preceito fundamental: I - quando for relevante o fundamento da controvérsia constitucional sobre lei ou ato normativo federal, estadual ou municipal, incluídos os anteriores à Constituição;

Art. 2o Podem propor arguição de descumprimento de preceito fundamental I - os legitimados para a ação direta de inconstitucionalidade.

Uma ação de anencefalia foi apresentada ao Supremo Tribunal Federal (STF), dia 17 de junho de 2004, por meio de uma Arguição de Descumprimento de Preceito Fundamental (ADPF), pela Confederação Nacional dos Trabalhadores na Saúde (CNTS), com suporte técnico da Anis - Instituto de Bioética, Direitos Humanos e Gênero ${ }^{50,51}$. A CNTS buscou junto ao Supremo Tribunal Federal solução definitiva para os casos em que a anomalia fetal inviabilizasse a vida, como acontece com os fetos anencefálicos ${ }^{52}$. Para a entidade, obrigar a mulher a manter uma gravidez, ciente de que o feto não sobreviverá após o parto, fere o princípio constitucional da dignidade da pessoa humana, previsto no art. $1^{\circ}$, inciso III, da Constituição Federal, e afeta o direito à saúde, também previsto na Constituição, em seus artigos $6^{\circ}$ e 196. Outro argumento é o de que a antecipação terapêutica do parto não é vedada no ordenamento jurídico brasileiro, portanto, sua realização não pode ser proibida, sob pena de ofensa ao princípio da legalidade, previsto no art. $5^{\circ}$, inciso II, da $\mathrm{CF}^{53}$.

Meses antes, ainda em 2004, um primeiro pedido de habeas corpus chegou com a solicitação de uma grávida de anencéfalo que tentou, sem sucesso, uma decisão judicial que lhe garantisse o direito de interromper a gravidez ${ }^{14}$. O julgamento desse processo foi iniciado, mas ao longo dele o tribunal recebeu a informação de que a mulher havia dado à luz e a criança viveu por 7 (sete) minutos. Em razão disso, o julgamento foi encerrado sem uma definição ${ }^{14}$.

Na ação, a entidade (CNTS) defende a descriminalização da antecipação terapêutica do parto em caso de gravidez de feto anencéfalo ${ }^{53}$, ressaltou os preceitos fundamentais, concernentes aos princípios da dignidade da pessoa humana, da legalidade em seu conceito maior, da liberdade e autonomia da vontade bem como os relacionados à saúde e argumentou na que a permanência de feto anencéfalo no útero da mãe é potencialmente perigosa, podendo gerar danos à saúde e à vida da gestante e que impor à mulher o dever de carregar, por 9 (nove) 
meses, um feto que se sabe, com toda certeza que não sobreviverá, causa a gestante dor, angústia e frustração, resultando em violência às vertentes da dignidade humana, à liberdade e autonomia da vontade ${ }^{14}$.

Ainda em 2004, foi concedida liminar para autorizar a antecipação do parto quando a anencefalia fosse identificada por meio de laudo médico. Porém, pouco mais de três meses após, o Plenário do STF decidiu, por maioria de votos, cassar a autorização concedida ${ }^{53}$.

A discussão, bastante controvertida, foi tema de audiência pública em 2008, ocasião em que foram ouvidos representantes do governo, especialistas em genética, entidades religiosas e da sociedade $\operatorname{civil}^{53}$.

No dia 12 de abril de 2012, depois de quase 8 anos de discussão, o Supremo Tribunal Federal (STF) aprovou a antecipação terapêutica da gestação de fetos anencéfalos com oito votos a favor e apenas dois contra ${ }^{54}$. Portanto a situação clínica da anencefalia não se enquadra na determinação penal do crime de aborto (enquadra-se como antecipação terapêutica de fetos anencéfalos), pois para que se sustente o argumento de aborto, é preciso que haja expectativa de vida extrauterina, algo inexistente para o feto com anencefalia ${ }^{50}$. A partir dessa decisão, as mulheres que comprovadamente estejam grávidas de fetos anencéfalos, não precisam maios recorrer a Justiça para interromper a gravidez ${ }^{83}$. Então a anencefalia passou a ser equiparada à morte encefálica e, portanto, permitida na legislação brasileira (art. 128 do Código Penal), que considera atualmente o aborto como crime punível, exceto em condições de risco de vida materna ou quando a gravidez for resultado de estupro ${ }^{55,56}$.

Segundo o Min. Marco Aurélio de Mello, a interrupção da gravidez no caso de feto anencefálico não caracteriza aborto, porque não há expectativa de vida fora do útero ${ }^{87}$. Barroso $^{51}$, ressaltou em seu voto, que "obrigar uma mulher a carregar um feto que não tem expectativa de vida, é violar sua integridade física e psicológica". O Procurador-Geral da República, Roberto Gurgel, defendeu que a própria gestante tenha autonomia para decidir sobre a antecipação do parto nos casos de fetos anencéfalos. Segundo ele, cabe à mulher decidir com sua própria consciência sobre a interrupção da gravidez, e essa decisão não pode ser proibida ou criminalizada pelo Estado ${ }^{53}$.

Borges $^{53}$ também trouxe o posicionamento de alguns Ministros do STF. A ministra Rosa Maria Weber sustentou que, para o direito, o que está em jogo, no caso, não é o direito do feto anencefálico à vida, já que, de acordo com o conceito de vida do Conselho Federal de Medicina, jamais terá condições de desenvolver uma vida com a capacidade psíquica, física e afetiva inata ao ser humano, pois não terá atividade cerebral que o qualifique como tal. $\mathrm{O}$ que está em jogo, portanto, segundo ela, é o direito da mãe de escolher se ela quer levar adiante uma gestação cujo fruto nascerá morto ou morrerá em curto espaço de tempo após o parto, sem desenvolver qualquer atividade cerebral, física, psíquica ou afetiva, própria do ser humano. 
Nesse mesmo sentido, voto também o Ministro Joaquim Barbosa. Para o Ministro Luiz Fux, impedir a interrupção da gravidez sob ameaça penal efetivamente equivale a uma tortura, vedada pela Constituição Federal. A Ministra Carmem Lúcia ressaltou que a questão discutida seria o direito à vida e à liberdade, considerada a possibilidade jurídica da grávida de feto anencéfalo escolher qual seria o melhor caminho a ser seguido, quer continuando, quer interrompendo a gravidez. Enfatizou também o princípio constitucional da dignidade da vida e o direito à saúde, salientando, ainda, que, quando se fala em dignidade, todos os membros da família - a mãe, o pai e os irmãos mais velhos - estão envolvidos, pois todos têm expectativas no nascimento do bebê.

Já O ministro Ricardo Lewandowski divergiu e votou pela improcedência do pedido formulado na ADPF 54. Segundo ele, o STF só pode exercer o papel de legislador negativo, cabendo a função de extirpar do ordenamento jurídico as normas incompatíveis com a Constituição. Ele enfatizou também a possibilidade de que uma decisão favorável ao aborto de fetos anencéfalos torne lícita a interrupção da gestação de embriões com diversas outras patologias que resultem em pouca ou nenhuma perspectiva de vida extrauterina. Citando dados da Organização Mundial de Saúde sobre malformações congênitas, deformidades e anomalias cromossômicas, Lewandowski ressaltou que existem dezenas de patologias fetais em que as chances de sobrevivência são nulas ou muito pequenas.

O Ministro Ayres Britto afirmou que não se pode falar em aborto de anencéfalo porque o que as mulheres carregam no ventre, nesses casos, é um natimorto cerebral, sem qualquer expectativa de vida extrauterina. Segundo o ministro, a gravidez se destina à vida, e não à morte. Por isso, concluiu que o fato seria atípico.

Já o Ministro Gilmar Mendes considerou a interrupção da gravidez de feto anencéfalo como hipótese de aborto, visto que o feto anencéfalo poderia nascer com vida, ainda que breve. Assim, entendeu inadequado tratar o fato como atípico, porquanto parte da sociedade defenderia a vida e a dignidade desses fetos. Por isso, considerou a possibilidade de interpretar o aborto de anencéfalo a partir das opções legislativas já existentes acerca da isenção de punibilidade para o aborto em geral, previstas no $\mathrm{CP}$, que transitariam entre o estado de necessidade e a inexigibilidade de conduta diversa. Nesse sentido, consignou que a gestação de feto anencéfalo representaria maior risco para a saúde da mãe do que uma gravidez comum, do ponto de vista físico, embora não atingida a gravidade requerida no art. 128, I, do CP. Por sua vez, a saúde psíquica da genitora também seria vulnerada, dado o sofrimento decorrente do diagnóstico da condição do feto.

O Ministro Celso de Mello votou pela procedência do pedido da ADPF 54. Em seu voto, salientou que o STF não está legitimando a prática indiscriminada do aborto, uma vez que há uma grande diferença entre legalização do aborto e a antecipação terapêutica do parto em 
caso de anencefalia. Em contrapartida, o Ministro Cezar Peluso votou pela improcedência do pedido da ADPF 54, acompanhando a divergência aberta pelo ministro Ricardo Lewandowski. O ministro lembrou, ainda, que a questão dos anencéfalos tem de ser tratada com muita cautela, diante da imprecisão do conceito, das dificuldades do diagnóstico e dos dissensos em torno da matéria, consignando que a morte encefálica seria distinta da anencefalia, a qual integraria, ainda que brevemente, processo contínuo e progressivo da vida.

Do ponto de vista bioético, pode haver um conflito de valores entre a mãe gestante e o feto anencéfalo; contudo, de acordo com Marques $^{88}$, se este não tem nenhuma viabilidade, o conflito inexiste; logo, a mulher gestante de feto anencéfalo tem o direito de decidir pela manutenção ou não da gravidez e tal decisão não ultraja a bioética e seus fundamentos.

Anteriormente a decisão do STF, mulheres que recebiam o pesado diagnóstico de estarem gestando fetos anencéfalos tinham que levar a gravidez até o final ou solicitar à justiça autorização para a sua interrupção ${ }^{81}$. Porém, elas não tinham garantias de obter a autorização, afinal, dependiam da interpretação que o juiz ou promotor daria a cada caso ${ }^{50}$. Esse quadro de exigência de autorização judicial para o procedimento médico era ainda mais agudo para as mulheres usuárias do Sistema Único de Saúde (SUS), no qual o controle de legalidade do procedimento é maior e, de forma concreta, constitui condição para o direito à assistência ${ }^{32,50}$.

Entretanto há aquelas mães que, pela fé ou por motivos filosóficos, morais, de costume queiram dar prosseguimento à gravidez. A decisão do STF não excluiu o direito das pessoas de encarar tal situação e de tratar o anencéfalo como um filho que irá nascer e dar algum tipo de alegria a essa família que o aceitar como ele se apresenta. Tal julgamento não quis vendar os olhos das crenças ou acorrentar o direito de família, mas dar oportunidade a todos para escolher seus caminhos ${ }^{57}$.

O Conselho Federal de Medicina regulamentou a decisão do STF através da Resolução CFM $n^{\circ} 1.989 / 2012$, que dispõe sobre o diagnóstico de anencefalia para a antecipação terapêutica do parto $^{53}$. A resolução propõe (Resolução CFM No 1.989/2012, 2012):

Art. $1^{\circ} \mathrm{Na}$ ocorrência do diagnóstico inequívoco de anencefalia o médico pode, a pedido da gestante, independente de autorização do Estado, interromper a gravidez.

Art. $2^{\circ} \mathrm{O}$ diagnóstico de anencefalia é feito por exame ultrassonográfico realizado a partir da $12^{\mathrm{a}}$ (décima segunda) semana de gestação e deve conter:

I - duas Fotografias, identificadas e datadas: uma com a face do feto em posição sagital; a outra, com a visualização do polo cefálico no corte transversal, demonstrando a ausência da calota craniana e de parênquima cerebral identificável;

II - laudo assinado por dois médicos, capacitados para tal diagnóstico.

Art. $3^{\circ}$ Concluído o diagnóstico de anencefalia, o médico deve prestar à gestante todos os esclarecimentos que lhe forem solicitados, garantindo a ela o direito de decidir livremente sobre a conduta a ser adotada, sem impor sua autoridade para induzi-la a tomar qualquer decisão ou para limitá-la naquilo que decidir: 
$\S 1^{\circ}$ É direito da gestante solicitar a realização de junta médica ou buscar outra opinião sobre o diagnóstico.

$\S 2^{\circ}$ Ante o diagnóstico de anencefalia, a gestante tem o direito de:

I - manter a gravidez;

II - interromper imediatamente a gravidez, independente do tempo de gestação, ou adiar essa decisão para outro momento.

$\S 3^{\circ}$ Qualquer que seja a decisão da gestante, o médico deve informá-la das consequências, incluindo os riscos decorrentes ou associados de cada uma.

$\S 4^{\circ}$ Se a gestante optar pela manutenção da gravidez, ser-lhe-á assegurada assistência médica pré-natal compatível com o diagnóstico.

$\S 5^{\circ}$ Tanto a gestante que optar pela manutenção da gravidez quanto a que optar por sua interrupção receberão, se assim o desejarem, assistência de equipe multiprofissional nos locais onde houver disponibilidade.

$\S 6^{\circ}$ A antecipação terapêutica do parto pode ser realizada apenas em hospital que disponha de estrutura adequada ao tratamento de complicações eventuais, inerentes aos respectivos procedimentos.

Art. $4^{\circ}$ Será lavrada ata da antecipação terapêutica do parto, na qual deve constar o consentimento da gestante e/ou, se for o caso, de seu representante legal.

Parágrafo único. A ata, as fotografias e o laudo do exame referido no artigo $2^{\circ}$ desta resolução integrarão o prontuário da paciente.

Art. $5^{\circ}$ Realizada a antecipação terapêutica do parto, o médico deve informar à paciente os riscos de recorrência da anencefalia e referenciá-la para programas de planejamento familiar com assistência à contracepção, enquanto essa for necessária, e à preconcepção, quando for livremente desejada, garantindo-se, sempre, o direito de opção da mulher.

Parágrafo único. A paciente deve ser informada expressamente que a assistência préconcepcional tem por objetivo reduzir a recorrência da anencefalia.

Na maioria dos países desenvolvidos, a legislação também permite o aborto para salvar a vida da gestante, preservar a sua saúde física ou mental, quando a gravidez resultou de estupro ou incesto, em casos de anomalia fetal, por razões econômicas ou sociais e por solicitação da mulher ${ }^{56,58}$. Em alguns países, conta-se com a gratuidade por parte do Estado desse procedimento $^{59}$.

Todavia pesam contra a decisão do STC casos como o da menina Marcela de Jesus. Ela nasceu dia 20 de novembro de 2006, em Patrocínio Paulista (SP), ficou famosa após ser diagnosticada como anencefalia, porém conseguiu viver por um ano, oito meses e doze dias ${ }^{60}$. Aos quatro meses de gestação, Marcela foi diagnosticada com anencefalia - má formação congênita que supõe a rápida morte do bebê devido à carência parcial ou total de cérebro ${ }^{28}$. A sua mãe, Cacilda Galante Ferreira, fez acompanhamento pré-natal durante os nove meses da gravidez e não apresentou nenhuma complicação decorrente da gestação ou do parto cirúrgico ${ }^{48}$. Marcela viveu monitorada por médicos, respirava e se alimenta através de tubos. Ela não tinha o córtex cerebral, mas tinha o tronco cerebral que é responsável pela respiração e pelo batimento cardíaco. Marcela faleceu de em razão de uma parada cardiorrespiratória, devido a uma forte pneumonia por aspiração de leite ${ }^{28}$. Esse caso ficou famoso no Brasil por sua polêmica e por gerar divergências entre os especialistas quanto ao exato diagnóstico da anencefalia ${ }^{14}$. Marcela também se transformou no ícone daqueles que se posicionavam contrários à permissão do 
aborto de anencéfalos, enquanto os favoráveis temiam que a sobrevivência influenciasse a decisão do Supremo Tribunal Federal, ainda que ela fosse vista como um caso raro e isolado ${ }^{48}$.

Diante desse quadro surge a polêmica: a questão que envolve a legalidade do aborto nos casos de anencefalia existe porque diante dessa realidade verificam-se direitos fundamentais envolvidos na situação problema. De um lado, há o direito à vida intrauterina do anencéfalo, resguardado pela Constituição. De outro, os direitos à saúde física, psíquica e social e à liberdade de autonomia reprodutiva da mulher, que também são protegidos constitucionalmente ${ }^{14}$. Em verdade, a discussão acerca do aborto do feto anencefálico ainda não chegou ao seu fim: o debate envolve questões religiosas, morais, éticas e as concepções sobre a origem da vida fetal, o que o torna árduo e vivo na sociedade ${ }^{52}$.

\section{Discussões Sobre Direito e Anencefalia}

O aborto decorrente de anomalia fetal, como é o caso da anencefalia, somente passou a ser discutido a partir de 1950, com o desenvolvimento de técnicas de diagnóstico pré-natal ${ }^{34}$. Neves ${ }^{61}$ lembra que, com as inovações tecnológicas, ocorrem situações para as quais o médico, a mulher e a família não estão preparados. Nesse sentido, esse é um assunto que envolve muitas questões, pontos de vista, principalmente de cunho ético e religioso, mas, num pensamento mais racional e até humanista, quando se pensa nas pessoas que passam por essa situação, se vê que essa é uma possibilidade que deve sim ser estudada para que se acabe com o sofrimento injusto das famílias que passam por essa situação ${ }^{45}$.

É com base na ordem jurídica de um país laico e democrático de direito como o Estado brasileiro, que permite debater amplamente a questão da interrupção da gravidez de fetos portadores de anencefalia, despindo-se de dogmas e valores religiosos e elevando a dignidade humana como princípio supremo, bem como a liberdade da mãe ao decidir se quer ou não prosseguir com a gestação, embora consciente de que poderá ver seu filho vivo, por apenas alguns minutos ${ }^{62}$.

As discussões têm incidido sobre abortamento, em face do que se denomina 'antecipação terapêutica do parto' ${ }^{12}$. Diniz ${ }^{44}$, Faúndes e Barzelato ${ }^{63}$ referem que "aborto" não é o termo mais adequado para indicar a interrupção da gestação, já que este designa a morte de um feto que tem potencial para transformar-se em um Ser humano. Esses autores lembram que $50 \%$ dos fetos anencéfalos morrem no útero materno, $49 \%$ sobrevivem menos de 24 horas após o parto e $1 \%$ vivem apenas uma semana. Dessa forma, a interrupção da gravidez de feto anencefálico não é considerada prática abortiva de acordo com a literatura médica e jurídica do tema, mas sim uma intervenção terapêutica, já que nesses casos trata-se de um feto com vida extrauterina inviável ${ }^{2}$. Massud ${ }^{12}$ refere ainda que a criança anencéfala é um ser humano, 
evidentemente, mas de uma incompletude que lhe retira características comuns aos seres de sua espécie, revelada esta por padrões de comportamento herdados, possibilidades, potencialidades, plasticidade. Não são diferenças de pequena monta, mas naquilo que é fundamental à sobrevivência e caracterização da pessoa. Não existe pessoa sem encéfalo e, portanto, não existe 'vir a ser' em relação aos anencéfalos. Portanto, os termos parto terapêutico e antecipação de parto de feto inviável seriam os termos apropriados para denominar a interrupção da gestação de feto anencéfalo ${ }^{64}$

Também ressaltam uma contradição na lei brasileira, pois esta considera como morto um indivíduo com morte encefálica, autorizando desse modo a retirada de órgãos para transplante, assim, o anencéfalo se enquadraria nesse caso, pois se este não possui cérebro, então já nasceria com morte cerebral, podendo até ter seus órgãos retirados para transplantes, viabilizando até a continuidade de outras vidas ${ }^{45}$.

Assim, a permissão da prática da antecipação do parto do feto anencefálico tem sido um assunto de muita polêmica no meio jurídico e científico ${ }^{28}$. No cerne dos inevitáveis embates, interfere a motivação religiosa, notadamente por parte da Igreja Católica, enfaticamente manifestada ${ }^{65}$. Esta é a oposição mais ferrenha aos defensores da antecipação do parto de feto anencéfalo $^{45}$. Marques ${ }^{66}$ também relata que o que vem causando mais dúvidas e obstando uma normatização do fato, é a influência que a igreja católica exerce, que considera a legalização da interrupção da gestação do anencéfalo uma brecha perigosa para permissões semelhantes. Conforme nota oficial, a Confederação Nacional dos Bispos do Brasil ${ }^{66}$ afirmou que 'a igreja é a favor da vida e da dignidade do ser humano, não importando o estágio do seu desenvolvimento, ou a condição na qual ele se encontre. A vida é um dom de Deus e deve ser respeitada desde o início até o seu final natural'.

É evidente que este tema desperta emoções muito fortes diante da realidade devastadora da teratologia humana, expressada nesta malformação terrível ${ }^{12}$. Em geral, o diagnóstico da anencefalia é dado na ecografia em que as mulheres procuram identificar o sexo do bebê, um momento quase mágico da gestação em que se tomam decisões familiares e afetivas, como escolha do nome, enxoval ou arquitetura do quarto. Isto faz com que o diagnóstico da anencefalia no feto ocorra em um momento da gestação em que as mulheres já são mães em potencial ${ }^{44}$. Existe um aspecto muito importante e que diz respeito ao Ser da mulher que concebe outro Ser, esperando-se que o produto da concepção seja uma nova vida. Se isto não ocorrer, em função de um diagnóstico pré-natal que sinaliza para a morte, a mulher e os profissionais de saúde são acometidos por um sentimento de culpa, impotência, frustração e depressão ${ }^{64,67}$.

Sabe-se também que, com a perda do encéfalo, perde o ser humano estruturas como o hipotálamo, tálamo, cerebelo e núcleos da base, que controlam a maioria das funções sem as 
quais a vida é impossível e absolutamente vegetativa. A ausência do córtex cerebral e do diencéfalo impede o estabelecimento de padrões emocionais, como raiva, excitação, resposta sexual, reação para dor e reação de prazer $^{12}$. O córtex é essencial para a maioria dos processos envolvidos com o pensamento e memória; sem ele a função dos outros centros é imprecisa, pois são seus comandos que tornam as operações desses centros precisas e determinativas. Falta, como já salientado, o hipotálamo, estrutura cerebral que participa ativamente da homeostase e, sem ele, há ausência de estimulação hipofisária e, consequentemente, das glândulas por ela estimuladas, como as adrenais, já caracteristicamente atrofiadas ao nascimento. Não há, pois, homeostasia, ou seja, manutenção do meio interno. Não há controle da temperatura corporal na ausência de função hipotalâmica, levando o pequeno organismo malformado a um estado de pecilotermia $^{67,68}$.

Diante de tantas deficiências, o que sobra não sustenta a vida por muito tempo, que fica à cargo de batimentos cardíacos que propelem o sangue e às incursões respiratórias, necessários à hematose e à oxigenação dos tecidos que guardam ainda vitalidade, até que o desequilíbrio total se instale à falta de homeostasia e a criança sucumba inevitavelmente, com ou sem o auxílio de cuidados intensivos ${ }^{12}$.

Portanto em relação a esse tipo de gestação podemos dizer que não há expectativa de vida para o feto e que se trata de uma gravidez que, invariavelmente, traz muito sofrimento para a gestante, os familiares e os amigos, sem nenhum benefício evidente que pudesse advir dela ${ }^{69}$.

Já em relação às possíveis intercorrências negativas à saúde física da mulher, estão o polihidrâmnio, que é o excesso de líquido amniótico - ocorre em até $75 \%$ dos $\operatorname{casos}^{18}$, o desenvolvimento de doenças hipertensivas e as complicações no momento do parto, que tem seu tempo médio aumentado, já que o feto não possui os ossos da cabeça necessários para empurrar o colo do útero e promover a dilatação para o nascimento ${ }^{57,70}$. Pelo fato da mulher não amamentar, também a involução uterina é mais lenta, suscitando sangramentos às vezes de grande monta no puerpério ${ }^{1}$.

É então uma gestação terrivelmente sofrida: a maioria das gestantes fica bastante abalada emocionalmente diante do diagnóstico e prognóstico ${ }^{18}$. Primeiro, porque se sabe de antemão que dela não resultará um bebê viável e, segundo, pelos riscos para a saúde da gestante, que são bem maiores que os de uma gravidez de um feto normal ${ }^{101}$. Dessa maneira, os casais que vivenciam tal situação e os profissionais de saúde que os assistem, deparam-se com um dilema ético, o qual envolve questões referentes à vida e à morte ${ }^{94}$. Assim, a caracterização do aborto como problema de saúde pública não é fruto apenas da sua elevada magnitude, mas também de seus efeitos para a saúde ${ }^{24}$.

A Febrasgo (Federação Brasileira das Associações de Ginecologia e Obstetrícia) publicou uma pesquisa em 2009, realizada com 1.814 médicos da instituição, relatando que das 
9.730 mulheres atendidas nos últimos 20 anos com o diagnóstico de gravidez de anencéfalo, 85\% decidiram por interromper a gestação. Nesse fato, particularmente, percebemos que, pelos relatos vistos nos diversos canais de informação, é gerado na mãe, exceto quando esta se apega à religião, uma vontade de finalizar a agonia de se esperar meses de gravidez, viver um parto doloroso e, depois de pouco tempo de nascimento, ver seu filho num caixão ${ }^{57}$.

Diante do exposto, pode-se observar que se trata de um tema muito controvertido não só na área jurídica, pelos efeitos que possa causar, mas também, nas áreas médica e principalmente da ética, assim a interrupção da gravidez de fetos anencéfalos é um assunto que gera muito clamor e discussão nos dias de hoje $\mathrm{e}^{45}$.

\section{Aborto, Anencefalia e o Direito das mulheres: um breve ensaio como considerações finais}

Os temas éticos suscitados pela anencefalia dizem respeito à vida e à dignidade humanas, como salienta Barroso ${ }^{103}$, entre o direito à vida do feto e a autonomia das mulheres ${ }^{12}$.

Entende-se que a vida do nascituro é um bem que está protegido pela Constituição. Não obstante, o problema surge quando a manutenção de uma gravidez não desejada viola os direitos fundamentais da gestante, resultando num conflito entre seus direitos e os interesses do embrião/feto $^{71}$. Não se pode esquecer que a vida da mulher também está em jogo nesse contexto. Sabe-se que a gestante de um feto anencéfalo é considerada portadora de uma gravidez de risco, já que pode apresentar prolongamento da gestação além de 40 semanas, dificuldades obstétricas e complicações no desfecho do parto, puerpério com maior incidência de hemorragias maternas por falta de contratilidade uterina; e maior incidência de infecções pós-cirúrgicas devido às manobras obstétricas do parto de termo, entre outras ${ }^{72}$. É nessa dogmática, que se reflete sobre a arbitrariedade me se privar a vida, ou seja, a problematicidade do aborto em face de aspectos relativos à tutela de outros valores jurídicos, como a saúde física da gestante, por exemplo ${ }^{73}$.

Existe neste ponto um conflito claro entre o direito à vida do nascituro, com o direito da gestante. Nesse ponto, a primeira vista, o direito da gestante, após as justificantes legais, se sobressai perante o direito à vida do nascituro. A questão primordial é, até que ponto o direito da gestante é mais importante do que o direito de viver de um nascituro? A vida não seria um bem maior a ser preservado? A resposta não é sempre favorável á vida, tendo em vista que a gestante também possui alguns direitos, que até certo ponto, mesmo legais, na opinião deste subscritor não são morais e muito menos civilizados ${ }^{74}$.

Evidencia-se, portanto, que vários princípios éticos e morais estão envolvidos nessa questão. Dentre estes princípios, podemos citar: Princípios Morais, Éticos, Sociais, Filosóficos, Científicos e Jurídicos - fatores que podem ser compreendidos como alicerces -ou melhor 
dizendo como base e estrutura de todos os direitos fundamentais e garantias que protegem os direitos humanos ${ }^{75}$.

É importante destacar que o feto anencéfalo, mesmo sendo considerado como um ser indefeso, prematuro, e incapaz na acepção do termo, ele possui o direito de existir, o direito de viver, e de ser bem recebido pelos seus genitores, e pela comunidade social de uma forma geral $^{75}$.

Se todos os seres humanos têm o direito de viver com dignidade; e se este é um princípio deontológico do direito em si, e não só do direito constitucional; é mais do que importante observarmos, que nos dias atuais; vários "passos" que a ciência tem dado, como por exemplo: Aborto, Clonagem Humana, Direito de Morrer e Eutanásia, e a Experimentação em Seres Humanos; vem afrontando em determinados aspectos os valores humanos, reduzindo a condição de ser humano, a condição de simples material ${ }^{75}$.

Nesse contexto, o direito à vida torna-se o mais fundamental de todos os direitos, constituindo em pré-requisito à existência e exercício de todos os demais direitos ${ }^{41,49}$, constituindo um fundamento para a efetivação de todos os outros direitos, como a liberdade, a integridade física, dentre outros ${ }^{41}$.

Sendo assim, corresponde ao nascituro direito à vida e não sobre a vida, assim como a todos os direitos inerentes a ela desde a concepção, sendo eles proteção contra o aborto, proteção material e moral. Todavia, relaciona-se também na esteira desse entendimento o direito da gestante em prol de uma gestação segura e saudável, quando o fruto da concepção traga riscos a saúde psíquica e física da mesma, é o caso da gestação de risco, exemplo é o feto anencéfalo, isso porque a anencefalia é uma das mais graves mal formações fetais congênitas, incompatível com a vida extrauterina, a qual por teoria ainda distorcida da Doutrina, gera o aborto por estado de necessidade ou aborto eugênico ${ }^{73}$.

\section{Referências}

1 - Febrasgo, Federação Brasileira das Associações de Ginecologia e Obstetrícia (2007). Anencefalia: Posição da FEBRASGO. 2007. Disponível em: http://www.febrasgo.org.br/anencefalia1.htm.

2 - Silva MH, Rodrigues MFSR, \& Amaral WN. (2011). Aspectos médicos e psicológicos de grávidas portadoras de feto anencefálico. Rev. Femina. 39(10).

3 - Carvalho MHB, Brizot ML, Zugaib M. (2006). Malformações do sistema nervoso central. In: Pastore AR, Cerri GG (Eds). Ultra-sonografia em Ginecologia e Obstetrícia. Rio de Janeiro: Revinter; p. 209-20.

4 - Lima CAS.(2010). Aborto e Anencefalia. Curitiba: Juruá Editora. 
5 - Rodrigues, D. (2012). Aborto e anencefalia (trabalho de conclusão de curso). Presidente Prudente: Faculdades Integradas, Curso de Direito, Faculdade de Direito de Presidente Prudente.

6 - Pante FR, Madi JM, Araújo BF3, Zatti et al. (2011). Malformações congênitas do sistema nervoso central: prevalência e impacto perinatal. Revista da AMRIGS. 55(4):339-44.

7 - Silva C , Menegozzo MO. (2012) . Defeitos do fechamento do tubo neural: evolução da incidência no Brasil. Saúde Coletiva. 9(56):56-60.

8 - Fujimori E, Baldino CF, Sato APS, Borges ALV, \& Gomes MN. (2013). Prevalência e distribuição espacial de defeitos do tubo neural no Estado de São Paulo, Brasil, antes e após a fortificação de farinhas com ácido fólico. Cad. Saúde Pública. 29(1):145-154.

9 - Reis, AT, Santos, RDS, Mendes, TAR. (2011). Prevalence of congenital malformations in Rio de Janeiro, Brazil, between 2000 and 2006. Rev. enferm. 19(3):364-68.

10 - Xavier, LB. (2012). Crítica de habermas a teoria alexyana dos direitos fundamentais no aborto por anencefalia fetal. Revista da Faculdade Mineira de Direito. 15(30):219-237.

11 - Nunes, LAR. (2006). O princípio constitucional da dignidade da pessoa humana: doutrina e jurisprudência. São Paulo: Saraiva.

12 - Massud, M. (2010). Anencefalia numa perspectiva ética. Rev Bras Saúde Mater Infant. 10(2):263-70.

13 - Lima de Brito, AM, Costa, CDC. (2010). O direito fundamental ao aborto do feto anencéfalo. Artigo apresentado para composição da avaliação da IV Unidade de Direito Civil Direito de Família.Prof.: Salomão Resedá.

14 - Seabra, LLP, da Silva, MP. (2013). Anencefalia e Aborto, a Atual Decisão do Supremo Tribunal Federal. Caderno de Ciências Humanas e Sociais Aplicadas. 1(01).

15 - Alberto, MVL, Galdos, ACR, Miglino, MA, dos Santos, JM. (2010). Anencefalia: Causas de uma malformação congênita. Rev. de Neurociência. 18(2): 44-48.

16 - Aguiar MJB, Campos AS, Aguiar RALP, Lana AMA, Magalhães RL, Babeto LT. (2003). Defeitos de fechamento do tubo neural e fatores associados em recém-nascidos vivos e natimortos. J Pediatr (Rio J). 79(2):129-34.

17 - Maranha, LA, Augusto, LP, Zanine, SC, Araújo, JC. (2012). Acrania e outras falhas na formação dos ossos do crânio: uma revisão da literatura. J Bras Neurocirurg. 23(3):217-221

18 - ANIS. (2004). Anencefalia: o pensamento brasileiro em sua pluralidade. Brasília: Letras Livres, p.74.

19 - Brito VRDS, Souza FSD, Medeiros FDAL, Coura AS, Gadelha FHA, \& França, ISXD. (2012). Incidência de malformação congênita e atenção em saúde nas instituições de referência. Rev da Rede de Enferm do Nord-Rev Rene. 11(4).

20 - Marques, HS. (2006). A Anencefalia e o direito da mãe de interromper a gestação. trabalho de conclusão de curso. Presidente Prudente: Faculdades Integradas, Curso de Direito, Faculdade de Direito de Presidente Prudente. 
21 - Bodeus, Richard. (2007). Aristóteles-A justiça ea cidade. Edições Loyola.

22 - Diniz, GFC. (2013). Os domínios recalcitrantes do direito internacional: diversidade moral e religiosa no direito penal como óbice ao direito comum: O caso do aborto do feto anencéfalo. Brazilian Journal of International Law. 9(4).

23 - Silva, CB, Diniz, NM, Neto, RL (2013). O aborto no anteprojeto do novo código penal brasileiro: reflexões jurídicas e bioéticas. Revista de Bioética y Derecho. (29), 35-50.

24 - Anjos, KF et al. (2013). Aborto no Brasil: A Busca por Direitos.Saúde e Pesquisa. (1).

25 - Brasil. Ministério da Saúde. (2010). Atenção humanizada ao abortamento: Norma Técnica. Secretaria de atenção à saúde. Departamento de Ações Programáticas e Estratégicas. 2. ed. Brasília. Disponível em http://portal.saude.gov.br/portal/arquivos/pdf/atencao_humanizada.pdf

26 - NUCCI, GS. (2010). Código penal comentado. 10. ed. rev., atual. e ampl. São Paulo: Revista dos Tribunais.

27 - PRADO, LR. (2011). Curso de direito penal brasileiro, v.2: parte especial, arts. 121 a 249. 9. ed. rev., atual. e ampl. São Paulo: Revista dos Tribunais.

28 - Moisés, GMB. (2012). Tirar a vida: aborto do anencefálico. Fasem Ciências. 1(1):50-62.

29 - Wahabi HA, Abed Althagafi NF, Elawad M. (2007). Progestogen for treating threatened miscarriage. Cochrane Database Syst Rev. (3).

30 - Rios, LTM, Oliveira, RVB, Martins, MG. (2010). Anormalidades do primeiro trimestre da gravidez: ensaio iconográfico. Radiol Bras. 2010;43(2):125-32.

31 - Brasil. Ministério da Saúde. (2011). Atenção humanizada ao abortamento: Norma Técnica. Secretaria de atenção à saúde. Departamento de Ações Programáticas e Estratégicas. 2. ed ampliada. Brasília. Disponível em http://bvsms.saude.gov.br/bvs/publicacoes/atencao_humanizada_abortamento_norma_tecnica_2 ed.pdf.

32 - Brasil. Ministério da Saúde. Secretaria de Ciência, Tecnologia e Insumos Estratégicos. (2009). Departamento de Ciência e Tecnologia. 20 anos de pesquisas sobre aborto no Brasil. Brasília: Ministério da Saúde.

33 - Victora, CG et al. (2011). Saúde de mães e crianças no Brasil: progressos e desafios. Lancet. ;377( 9780):1863-1876.

34 - Diniz, D. (2013). Estado laico, objeção de consciência e políticas de saúde. Cad. Saúde Pública. 29(9):1704-1706.

35 - Cecatti, JG; Guerra, GVQL; Sousa, MH, Menezes, GMS. (2010). Aborto no Brasil: um enfoque demográfico. Rev. Bras. Ginecol. Obstet. 32(3):105-111.

36 - Diniz, D; Medeiros, M. (2010). Aborto no Brasil: Uma pesquisa domiciliar com técnica da urna. Cien Saude Colet. 15(1):959-96.

37 - Alves, JAG, Alves, NG, Ibiapina, FLP, Busgaib, RPS, Costa, FS (2010). Ameaça de aborto: conduta baseada em evidências; Threatened miscarriage: conduct based on evidences. Femina. 38(2):111-15 
38 - Rezende, J; Montenegro, CAB. (1999). Obstetrícia fundamental. 8.ed. Rio de Janeiro.

39 - Dias, APA, Silva, CADSD, Aguiar, GGD, Oliveira, GSD, Ferreira, LS, Dias, LA, Bueno, MDC. (2010). Infected abortion: epidemiology, diagnosis and management in emergency:[review]. Rev. méd. Minas Gerais. 20(2, supl. 1):6-10.

40 - Bitencourt, Cezar Roberto. (2010). Tratado de Direito Penal: parte especial. 10ª E.d. São Paulo: Saraiva.

41 - Cardin, VSG, Baptista Rosa, LC. (2012). Do Relativismo Ético e Jurídico do Aborto Quando da Realização da Redução Embrionária. Revista Jurídica Cesumar-Mestrado.12(2).

42 - Jesus, Damásio E. de. (2001). Direito Penal. Parte Especial. 24 ed. São Paulo: Saraiva, 1, v.2.

43 - De Melo, MH. (2012). Anencefalia. Revista Jurídica. 9(8).

44 - Diniz, D.(2006). Severina torturada. Olhares femininos, mulheres brasileiras. Série Anis 43. Brasília: LetrasLivres.

45 - Da Costa, DM; Sanchez, CJP. (2009). Interrupção da gravidez de fetos anencéfalos. Eticencontro de iniciação científica.3(3).

46 - De Zordo, S. (2012). Representações e experiências sobre aborto legal e ilegal dos ginecologistas-obstetras trabalhando em dois hospitais maternidade de Salvador da Bahia. Ciência \& Saúde Coletiva.17(7):1745-54.

47 - Bitencourt, Cezar Roberto. (2009). Tratado de direito penal, 2: parte especial. $9^{a}$ ed. São Paulo: Saraiva.

48 - Terruel SC. (2011). Saúde entre o social, o cientifico e o jurídico: o abortamento de anencéfalos [Dissertação]. Franca: Universidade Estadual Paulista.

49 - Moraes, A. (2003). Direito constitucional. 13. ed. São Paulo: Atlas.

50 - Diniz, Debora et al. A magnitude do aborto por anencefalia: um estudo com médicos. Ciênc Saúde Colet. 14(1):1619-24.

51 - Barroso LR. ADPF. (2004). Anencefalia. In: CREMEB. Anencefalia e Supremo Tribunal Federal. Brasília: LetrasLivres; p. 69-119.

52 - Mingati, VS; Góes, WP; Costa, IG. (2012). The anencephalic fetus abortion and the constitutional issue. Rev. bras. crescimento desenvolv. Hum.22(2):133-141.

53 - Borges, SM. (2012). A Questão Da Interrupção Da Gravidez De Feto Anencéfalo No STFUma Análise Da ADPF 54. Revista de Direito dos Monitores da Universidade Federal Fluminense. 5(12):101-14.

54 - De Oliveira, FR; Camargos, AF. (2011). Descriminalização do aborto de anencéfalos: a conquista de um direito e o início de vários dilemas éticos. Rev Femina. 39(6):124.

55 - França, GV. (2011). Medicina legal. 9. ed. Rio de Janeiro: Guanabara Koogan. 
56 - De sousa, MH. (2010). Aborto e legislação: opinião de magistrados e promotores de justiça brasileiros. Rev Saúde Pública. 44(3):3.

57 - Baptista, DOC. (2012). Anencéfalo: sujeito de laicização da morte. Belo Horizonte. Centro Universitário Metodista Izabela Hendrix.

58 - Faúndes A, Barzelatto J. (2004). O drama do aborto: em busca de um consenso. Campinas: Komedi.

59 - Marques, JMS. (2010). Anencefalia: interrupção da gravidez é uma liberdade de escolha da mulher?. Rev de Direito Sanitário.11(1): 151-164.

60 - Peixoto, FDF. (2010). Direito, Anencefalia e Antecipação Terapêutica do Parto: uma análise da realidade brasileira. Anais do XIX Encontro Nacional do CONPED.

61 - Neves MP. (1995). A fundamentação antropológica da bioética. In: $1^{\circ}$ Congresso de bioética da América Latina e Caribe. Seminário Sulamericano do Programa de Bioética para a América Latina. Flagrantes Bioética.

62 - Custódio AV, Poffo GD, Souza IF. (2013). Direitos fundamentais e Políticas Publicas. 21 e.d. Balneário Camboriu: AVANTIS.

63 - Faúndes A, Barzelatto J. (2004). O drama do aborto: em busca de um consenso. Campinas: Komedi.

64 - Barbosa, GC; Boemer, MR. (2009). A anencefalia sob a ótica da bioética: a perspectiva dos profissionais de enfermagem. Centro Universitário São Camilo.

65 - Conferência Nacional dos Bispos do Brasil. (2008). Nota da CNBB sobre Aborto de Feto "Anencefálico" Referente à Arguição de Descumprimento de Preceito Fundamental n. 54 do Supremo Tribunal Federal.

66 - Marques SH. (2006). A anencefalia e o direito da mãe de interromper a gestação. Faculdade de direito de presidente prudente.

67 - Guyton AC, Hall JE. (2006). Textbook of Medical Physiology. 17th ed. Philadelphia: Elsevier Saunders. p. 894.

68 - Gazzaniga MS, Iury RB, Magnun GR. (2006). Neurociência cognitiva. 2 ed. Trad. Angelica Rosat Consiglio et al. Porto Alegre: Artmed. p.88-113.

69 - Frias, L; Birchal, T. (2011). Aborto de fetos anencéfalos. An international Journal for Moral Philosophy. 8(1):19-30.

70 - Santos MAS. (2010). A (in)constitucionalidade da interrupção terapêutica de gestação de fetos anencéfalos. Rev Direitos Fundam Democr.7(7):119-53.

71 - Tessaro, A. (2006). Aborto, bem jurídico e direitos fundamentais [dissertação]. Porto Alegre: Pontifícia universidade católica do rio grande do sul.

72 - PINOTTI, J. A. Anencefalia: Opinião. Federação Brasileira das Associações de Ginecologia e Obstetrícia Disponível em: <http://www.febrasgo.org.br/anencefalia2.htm>.

73 - Mansano, J. (2011). Direitos do Nascituro. Revista Espaço Acadêmico. 11(121):99-107. 
74 - Junqueira, BF. (2012). Aborto: conflitos entre a legislação positivada e princípios éticos e morais. Anais do curso de extensão em teoria do direito:"a tríplice perspectiva do direito ea relação teórica, prática e ética.".

75 - Prado, FS. (2012). Anencefalia e o Direito à Vida. Revista Eletrônica da Faculdade de Direito de Franca. 5(1).

\section{How to cite this article (APA format):}

Jovino, Eduarda Monteiro; Barroso, Marianna Leite; Florêncio, Ana Karoline de Oliveira; Gonçalves Júnior, Jucier. (2019). Anencefalia enquanto Malformação Congênita e Questões Críticas Envolvidas. Am. In. Mult. J., October a December. (7) 4, 268-291.

Received: $12 / 12 / 2019$

Accepted: 12/18/2019 